\title{
Glutamatergic medications as adjunctive therapy for moderate to severe obsessive- compulsive disorder in adults: a systematic review and meta-analysis
}

Fatemeh Hadi ${ }^{1}$, Shayan Kashefinejad ${ }^{2}$, Leila Kamalzadeh ${ }^{2}$, Saba Hoobehfekr ${ }^{3}$ and Mohammadreza Shalbafan ${ }^{2,4^{*}}$

\begin{abstract}
Background: Obsessive-compulsive disorder (OCD) is among the most disabling neuropsychiatric conditions characterized by the presence of repetitive intrusive thoughts, impulses, or images (obsessions) and/or ritualized mental or physical acts (compulsions). Serotonergic medications, particularly Selective Serotonin Reuptake Inhibitors (SSRIs), are the first-line treatments for patients with OCD. Recently, dysregulation of glutamatergic system has been proposed to be involved in the etiology of OCD. We designed this systematic review and meta-analysis to evaluate clinical efficacy of glutamatergic medications in patients with OCD, according to the guidelines of Cochrane collaboration.
\end{abstract}

Method: We searched Medline, Scopus, and Cochrane library without applying any language filter. Two of the authors independently reviewed search results for irrelevant and duplicate studies and extracted data and assessed methodological quality of the studies. We transformed data into a common rubric and calculated a weighted treatment effect across studies using Review Manager.

Results: We found 476 references in 3 databases, and after exclusion of irrelevant and duplicate studies, 17 studies with total number of 759 patients with OCD were included. In the present review we found evidence for several drugs such as memantine, N-acetylcysteine (NAC), Minocycline, L-carnosine and riluzole. Glutamaterigic drug plus SSRIs were superior to SSRI+ Placebo with regard to Y-BOCS scale [standardized mean difference (SMD $=-3.8195 \%$ $\mathrm{Cl}=-4.4,-3.23)$.

Conclusion: Augmentation of glutamatergic medications with SSRIs are beneficial in obsessive-compulsive patients, no harmful significant differences in any safety outcome were found between the groups.

Keywords: Glutamate, Riluzole, Memantine, Minocycline, Obsessive-compulsive disorder, Systematic review

\footnotetext{
* Correspondence: Shalbafan.mr@iums.ac.ir

${ }^{2}$ Mental Health Research Center, Psychosocial Health Research Institute,

Department of Psychiatry, School of Medicine, Iran University of Medical Sciences, Tehran, Iran

${ }^{4}$ Brain and Cognition Clinic, Institute for Cognitive Sciences Studies, Tehran,

Iran

Full list of author information is available at the end of the article
}

(C) The Author(s). 2021 Open Access This article is licensed under a Creative Commons Attribution 4.0 International License, which permits use, sharing, adaptation, distribution and reproduction in any medium or format, as long as you give appropriate credit to the original author(s) and the source, provide a link to the Creative Commons licence, and indicate if changes were made. The images or other third party material in this article are included in the article's Creative Commons licence, unless indicated otherwise in a credit line to the material. If material is not included in the article's Creative Commons licence and your intended use is not permitted by statutory regulation or exceeds the permitted use, you will need to obtain permission directly from the copyright holder. To view a copy of this licence, visit http://creativecommons.org/licenses/by/4.0/. The Creative Commons Public Domain Dedication waiver (http://creativecommons.org/publicdomain/zero/1.0/) applies to the data made available in this article, unless otherwise stated in a credit line to the data. 


\section{Background}

Obsessive-compulsive disorder (OCD) is among the most disabling neuropsychiatric conditions characterized by the presence of repetitive intrusive thoughts, impulses, or images (obsessions) and/or ritualized mental or physical acts (compulsions) [1]. OCD affects approximately $1-2 \%$ of adult general population worldwide [2]. It is associated with significant functional impairment, both due to the primary illness, as well high comorbidity with other psychiatric disorders. Abnormalities in serotonin and/or dopamine neurotransmission have been suggested to underlie the development of OCD $[3,4]$.

Recommended first-line pharmacotherapies for OCD are serotonergic antidepressants, such as selective serotonin reuptake inhibitors (SSRIs) and clomipramine [5, 6]. However, estimates suggest that around $30-60 \%$ of patients do not improve or show a partial response to adequate serotonergic antidepressant treatment, implying that serotonergic dysregulation may not be the one but rather one of many important mechanisms that are involved in the pathophysiology of OCD.

Recently, researchers have proposed that glutamatergic dysfunction, especially in the cortico-striato-thalamocortical (CSTC) circuitry may play a key role in the pathophysiology of OCD $[7,8]$. Glutamate is the principal excitatory neurotransmitter in the central nervous system. It is also a precursor for gamma-amino butyric acid (GABA), the main inhibitory neurotransmitter in the brain, as well as for the amino acid glutamine and the antioxidant molecule glutathione [7]. Glutamate plays a vital role in various physiological processes including neuronal migration and cell maturation particularly by acting on N-methyl-D-aspartate (NMDA) and $\alpha$-amino-3-hydroxy-5-methyl-4-isoxazolepropionic acid (AMPA) receptors [9]. Abnormally elevated or reduced glutamate is shown to have adverse effect on cortical migration. The striatum, one of the major components of CSTC circuitry, is the largest group of receptive neurons in the basal ganglia, receiving a large glutamatergic excitatory input from the cortex [10]. Evidently, the striatum is responsible for planning cognitive and motor actions [7]. Aberrant glutamatergic signaling between orbitofrontal cortex (OFC), anterior cingulate cortex (ACC) and striatum have been widely recognized to be associated with the development of OCD [11]. Interestingly, recent evidence has also shown in vivo evidence for glutamatergic control of presynaptic serotonin release in the striatum. It is well known that dysregulation of the striatal serotonergic system is a primary pathology in OCD [12].

The most direct evidence suggesting altered glutamate homeostasis in OCD derived from cerebrospinal fluid (CSF) studies. These early studies demonstrated that glutamate is excessive in the CSF of a subset of untreated patients with OCD [13, 14]. Additional studies using magnetic resonance spectroscopy (MRS) indicated that glutamate and related compounds are elevated in the basal ganglia and reduced in the anterior cingulate cortex in patients with OCD $[7,15]$. There is also some evidence to suggest that polymorphisms in glutamateassociated genes may contribute to OCD risk [16]. Among the implicated glutamate-associated genes in OCD, the most consistent candidates are the SLC1A1 which encodes the neuronal glutamate transporter excitatory amino acid transporter 3 (EAAT3), and The SAPAPs (synapse associated protein 90/postsynaptic density-95-associated proteins)/ DLGAPs (disks largeassociated proteins) which are key components of the postsynaptic complex that anchors and spatially organizes glutamate receptors $[17,18]$.

Further to the aforementioned evidence on glutamatergic dysfunction in OCD, the potential benefits of some glutamate-modulating agents such as riluzole, memantine, N-acetylcysteine (NAC), D-cycloserine, and ketamine have been demonstrated in the treatment of OCD $[10,19]$. However, few writers have been able to draw on any systematic research into the potential utility of these agents. Hence, this paper will systematically review the research conducted on the clinical efficacy of glutamate-modulating agents in the treatment of patients with OCD, aiming to serve as a base for future studies in this area.

\section{Methods}

We conducted this systematic review in accordance with the Preferred Reporting Items for Systematic Reviews and Meta-Analyses for Protocols guidelines [20].

\section{Search strategy and selection criteria}

In this systematic review and meta-analysis, controlled clinical trials (irrespective of blinding and randomization) investigating clinical efficacy of glutamatergic drugs (irrespective of modes of administration, dosage, frequency and duration) in patients with OCD (irrespective of age, gender or race) were included (Appendix 1).

The primary search process was conducted in Web of Science, PubMed, Scopus, ScienceDirect, Cochrane library and Google Scholar databases based on the search strategies described in the protocol (Appendix 1) to gather the body of evidence available from original articles published up to 2021 in English. The first author conducted an electronic database search. Then, the titles and abstracts of studies initially selected were screened to eliminate duplicate citations and those that were obviously irrelevant. The full texts of the remaining studies were obtained for quality assessment, data collection and analysis. 


\section{Data extraction and quality assessment}

After the initial screening, the full texts were reviewed by two independent researchers to include eligible articles according to the inclusion criteria.

Detailed data extraction was performed based on the pre-designed data extraction forms. Extracted information included the study design, name and address of the corresponding author, participants' characteristics, interventions and outcomes. The methodological quality of the included studies was then evaluated according to the Cochrane risk of bias assessment tool [21]. In case of disagreement between authors, opinion was sought from a third author.

\section{Evidence synthesis}

We developed an evidence synthesis of the findings of the included studies using systematic approaches such as textual descriptions, tabulation, and transforming data into a common rubric using Review Manager (Version 5.3. Copenhagen: The Nordic Cochrane Centre, the Cochrane Collaboration, 2014). Missing data were handled using sophisticated statistical analysis techniques.

A meta-analysis was performed and the weighted average treatment effect was estimated. Heterogeneity across studies were evaluated by the chi-square statistic and calculation of $\mathrm{I}^{2}$ (defined as $\mathrm{I}^{2}>40 \%$ and/or chi-square statistic $p<0.1$. A random-effects model was used in the case of statistical heterogeneity. Moreover, we applied a subgroup analysis in case of clinical heterogeneity.

\section{Results}

\section{Description of included studies}

We found 476 studies of interest in the initial electronic searches. We then excluded 111 duplicate citations using Endnote software and 204 articles due to obvious irrelevancy of their topics in primary screening (Fig. 1). In secondary screening of 161 full texts, we excluded 144 articles, and finally included 17 controlled trials with 759 patients with OCD in this systematic review (Table 1).

Our primary outcome measure was the mean difference in Yale-Brown obsessive-compulsive score (YBOCS) ratings before and after pharmacological intervention in experimental and control groups. All except one of the included studies reported Y-BOCS final scores of each group. In the study which these data were not reported, we considered the proportion of treatment responders (as defined by a 35\% decline in Y-BOCS scores) in the experimental group compared to the

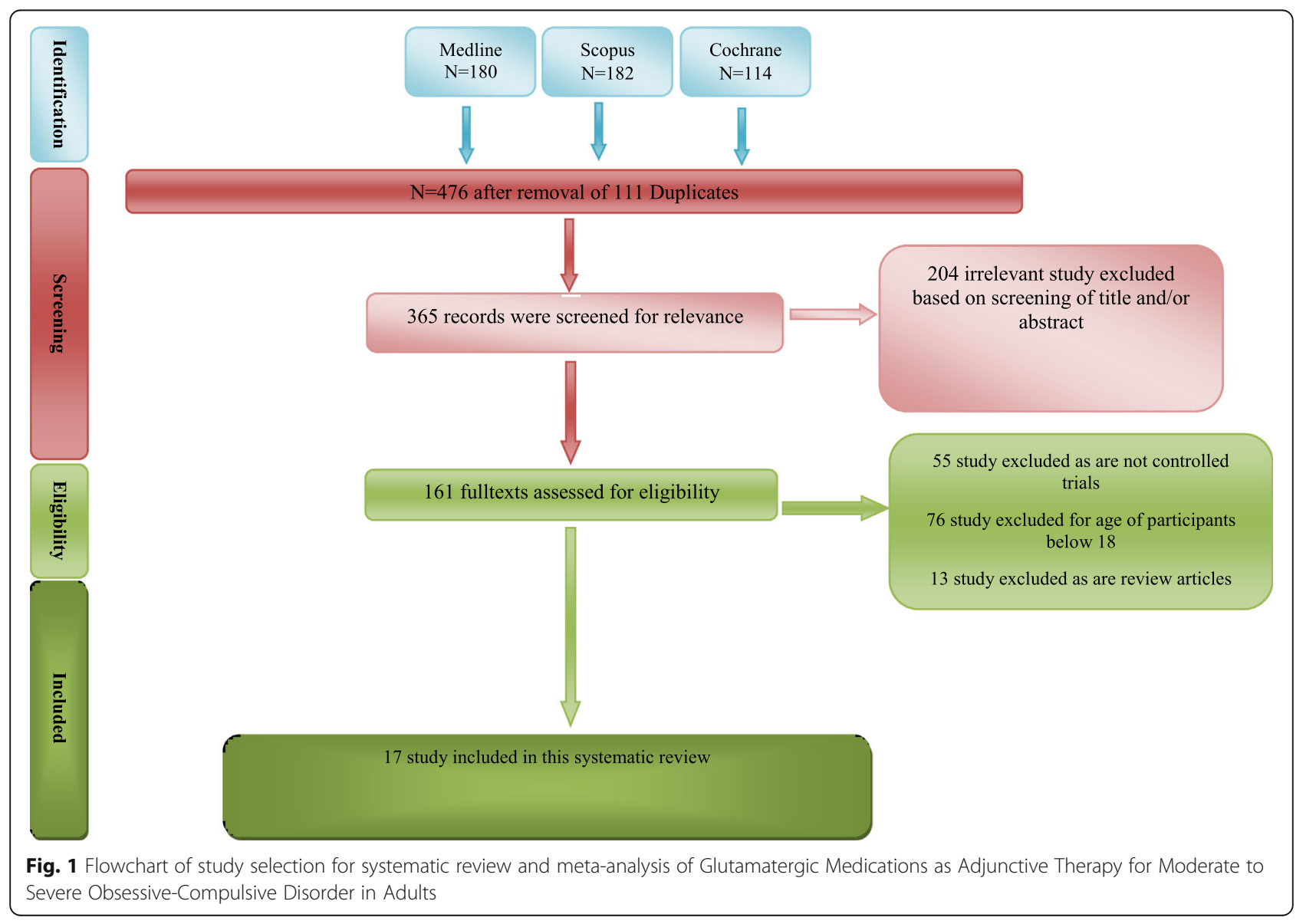


Table 1 Controlled clinical trials reporting Glutamatergic drugs in OCD

\begin{tabular}{|c|c|c|c|}
\hline & $\begin{array}{l}\text { Study (first } \\
\text { author, year of } \\
\text { study) }\end{array}$ & Study patients and main groups & Interventions \\
\hline 1 & $\begin{array}{l}\text { Afshar et al., } \\
2012\end{array}$ & $\begin{array}{l}\text { Patients with refractory } \mathrm{OCD}(n=38) \\
\text { 1- control group }(n=24) \\
\text { 2- experimental group }(n=24)\end{array}$ & $\begin{array}{l}\text { 1- Control group: placebo, identical } \\
\text { pills } \\
2 \text { - Experimental group: initial dosage } \\
\text { of } 600 \mathrm{mg} / \mathrm{d} \text { of NAC, which doubled } \\
\text { weekly to a maximum dose of } 2400 \mathrm{mg} / \\
\text { d } \\
\text { - Serotonin reuptake inhibitor treatment } \\
\text { continued throughout the study with } \\
\text { the same dose as the preintervention } \\
\text { phase } \\
\text { - } 12 \text { wks follow up }\end{array}$ \\
\hline 2 & $\begin{array}{l}\text { Arabzadeh et al., } \\
2017\end{array}$ & $\begin{array}{l}\text { Those with a diagnosis of moderate } \\
\text { to severe OCD defined by a Yale- } \\
\text { Brown Obsessive Compulsive Scale } \\
\text { (Y-BOCS) score of } \geq \mathbf{2 1} \text { (Goodman, } \\
\text { Price, Rasmussen, et al., 1989) were } \\
\text { included( } n=50) \\
\text { 1- control group ( } n=25) \\
\text { 2- experimental group }(n=25) \\
\text { Hepatectomy and radio-chemotherapy } \\
\text { were front-line therapies }\end{array}$ & $\begin{array}{l}\text { 1- Control group: Fluvoxamine ( } 200 \\
\text { mg) + placebo } \\
\text { 2- Experimental group: Fluvoxamine } \\
\text { ( } 200 \mathrm{mg} \text { daily) + L-carnosine } 500 \mathrm{mg} \\
\text { twice per day } \\
\text { - Follow up after } 10 \mathrm{wks}\end{array}$ \\
\hline 3 & $\begin{array}{l}\text { Costa et al., } \\
2017\end{array}$ & $\begin{array}{l}\text { Patients with OCD }(n=40) \\
\text { 1- control group }(n=22) \\
\text { 2- experimental group }(n=18)\end{array}$ & $\begin{array}{l}\text { 1- Control group: SRI + Placebo } \\
\text { 2- Experimental group: SRI + N-Acetyl } \\
\text { Cysteine } \\
\text { • } 16 \text { wks follow up } \\
\text { - During the first week, patients started } \\
\text { the trial with either NAC } 1200 \text { mg (one } \\
600-m g \text { capsule twice a day) or an } \\
\text { equivalent number of placebo capsules. } \\
\text { In the second week, the dosage was in- } \\
\text { creased to } 4 \text { capsules per day (NAC } \\
2400 \text { mg [ } 2 \text { capsules twice a day] or an } \\
\text { equivalent number of placebo cap- } \\
\text { sules). Finally, on the third week, the } \\
\text { target dose of } 5 \text { capsules per day was } \\
\text { reached (NAC } 3000 \text { mg [ } 2 \text { capsules in } \\
\text { the morning and } 3 \text { in the evening] or } \\
\text { an equivalent number of placebo cap- } \\
\text { sules) and sustained for the remainder } \\
\text { of the study. }\end{array}$ \\
\hline
\end{tabular}

4 Emamzadehfard Patients with OCD $(n=54)$ et al. $2016 \quad 1$ - control group $(n=27)$

2- experimental group $(n=27)$ according to the DSMIV-TR and a YaleBrown Obsessive Compulsive Scale $(Y$ BOCS) score of $\geq 21$
Outcomes, results and relationships

$>$ Y-BOCS: Mean difference $95 \% \mathrm{Cl} ;-$

$5.14[-6.87,-3.41]$

$>$ Adverse effects: no unusual or serious adverse event was observed. The adverse events reported during trial were only gastrointestinal.

Eight patients in the NAC group reported nausea/vomiting of mild to moderate intensity compared with 2 patients in the placebo group. Mild diarrhea was reported by 4 patients in the NAC group but none of the patients in the placebo group

$>$ Y-BOCS: Mean difference $95 \% \mathrm{Cl}$; $3.00[-4.70,-1.30] P$ value:0.01

$>$ Adverse effects: Headache 6 Dry mouth 6 Nausea 3 Constipation 6 Sweating Frequency of side effects was not different between the two groups.

$>$ Overall survival in 8 years* ${ }^{*} H R$; 95\%Cl; $P$ value): 0.69 (0.41-1.15); $P=$ 0.1545

$>$ Recurrence-free survival in $\mathbf{5}$ years* (HR; 95\%Cl; $P$ value): 0.31 (0.091.07); $P=0.0639$

$>$ Toxicity grade 3-4: none was reported

1. Control group: fluvoxamine $\mathbf{2 0 0}$ $\mathrm{mg} /$ day + placebo

2. Experimental group: fluvoxamine $200 \mathrm{mg} /$ day + riluzole $50 \mathrm{mg}$ BD 10 wks follow up

$>$ Y-BOCS: Mean difference $95 \% \mathrm{Cl}$; $3.56[-6.89,-0.23] p$ value:0.04 Adverse effects: Experimental group: Drowsiness, 6 (24\%) Constipation, 5 (20\%) 5 (20\%) Dizziness, 4 (16\%)Abdominal pain, n (\%) 5 (20\%) 4(16\%) Increased appetite, n (\%) $4(16 \%) 5(20 \%)$ Decreased appetite, $n$ (\%) 3 (12\%) 4 (16\%) Nausea, n (\%) 6 (24\%) 5 (20\%) Headache, n (\%) 4 (16\%) 4 (16\%) Dry mouth, n (\%) 3 (12\%) 3 (12\%) Cough, 4 (16\%) Diarrhea, 6 (24\%) 4 (16\%) Increase in liver-function tests (4\%) 0

$>$ Y-BOCS: Mean difference $95 \% \mathrm{Cl}$ $-3.21[-0.84--5.58] p$ value:0.008 $>$ Adverse effects: No difference between to gropus et al., 2016
Patients

1 - control group $(n=66)$

2- experimental group $(n=66)$

- Almost half of the patients had hepatitis B

- Hepatectomy or TACE were frontline therapies
1- Control group: Fluvoxamine 200 $\mathrm{mg} /$ day + placebo (identical, same shaped capsule) 2- Experimental group: Fluvoxamine $200 \mathrm{mg} /$ day + Minocycline $100 \mathrm{mg}$ twice daily 10 wks follow up 
Table 1 Controlled clinical trials reporting Glutamatergic drugs in OCD (Continued)

\begin{tabular}{|c|c|c|c|}
\hline & $\begin{array}{l}\text { Study (first } \\
\text { author, year of } \\
\text { study) }\end{array}$ & Study patients and main groups & Interventions \\
\hline 6 & $\begin{array}{l}\text { Farnia et al., } \\
2018\end{array}$ & $\begin{array}{l}\text { Patients with OCD }(n=99) \\
\text { 1- control group }(n=33) \\
\text { 2- experimental group } 1(n=33) \\
\text { 3- experimental group } 2(n=33)\end{array}$ & 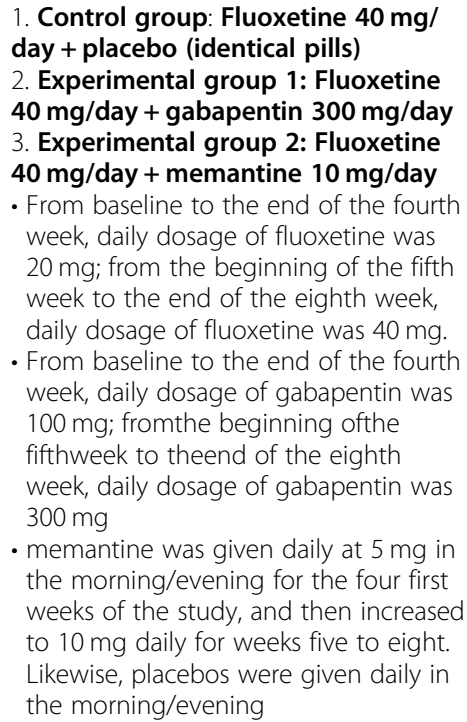 \\
\hline
\end{tabular}

7 Ghaleiha et al., Patients with OCD $(n=42)$ 2013 - control group $(n=21)$ - experimental group $(n=21)$

8 Greenberg et al., Patients with OCD $(n=24)$ 2009

- control group $(n=12)$

- experimental group $(n=12)$

9 Haghighi et al., 2013

\footnotetext{
Patients with OCD $(n=40)$

- control group $(n=20)$

- experimental group $(n=20)$
}

$\mathrm{mg} /$ day + placebo (with the same shape and taste as memantine) 2- Experimental group: fluvoxamine $200 \mathrm{mg} /$ day + memantine $\mathbf{2 0} \mathrm{mg} /$ day

- All patients received

fluvoxamine $100 \mathrm{mg} /$ day for the first four weeks of the trial followed by 200 $\mathrm{mg} /$ day for the rest of the study - 8 wks follow up

- The experimental intervention was

Outcomes, results and relationships

\section{$>$ memantine vs. placebo:}

Mean difference 95\% Cl: - 1.12 [-0.916,

- 3.1622] P-value:0.2

$>$ Gabapentin vs. placebo

Mean difference 95\% Cl: - 2.550[- 0.7895 , - 4.3105] P-value:0.0061

$>$ Adverse effects: More rash was seen in memantine group than control group Sleepiness was reported in gabapentin group

- Y-BOCS: has not reported the mean of score after the trial. Just reports remission rate

1. Control group: placebo fluid (dextrose, fructose, fine granular citric acid, orange flavoring and ProSweetTM flavor enhancer) 2. Experimental group: glycine powder $30 \mathrm{~g}$ dissolved in water or juice, twice daily adjunctive to participants' continuing psychotropic and psychotherapeutic regimens, which were managed by their treatment providers in the

community.

- 12 wks follow up

1- Control group: placebo (identical pill)

2- Experimental group: memantine (5-10 mg/day)

- All patients use medication 1 week prior to the beginning of the study (and continued throughout the study) of an SSRI (e.g., escitalopram, $10 \mathrm{mg} /$ day; citalopram, 30-50 mg/day) or clomipramine (100-175 mg/day) at therapeutic dosages for at least 12 consecutive weeks

.12 wks follow up
- Adverse effects in control group: Drowsiness (26\%) Headache (21\%) Constipation (31\%) Dizziness (21\%) Fatigue (16\%) Nausea (21\%) Decreased appetite (26\%) Itching (10\%) Nervousness (21\%) Rash (5\%) in experimental group: Drowsiness (21\%) Headache (16\%) Constipation (31\%) Dizziness 3 (16\%) Fatigue (16\%) Nausea (26\%) Decreased appetite (21\%) Itching (16\%)Nervousness (21\%) Rash (10\%)

$\triangleright$ Y-BOCS: Mean difference 95\%Cl; $-5.30[-11.56,0.96] ; p$ value: 0.1650 $>$ Adverse effects: constipation 1; nausea or disagreeable taste 8 out of 16 dropped patients

$>$ Y-BOCS: Mean difference $95 \% \mathrm{Cl}$; -3.21 [-0.84- - 5.58] $p$ value:0.008 $\triangleright$ Adverse effects: light-headedness and vertigo 5\% (similar to placebo group) 
Table 1 Controlled clinical trials reporting Glutamatergic drugs in OCD (Continued)

\begin{tabular}{|c|c|c|c|c|}
\hline & $\begin{array}{l}\text { Study (first } \\
\text { author, year of } \\
\text { study) }\end{array}$ & Study patients and main groups & Interventions & Outcomes, results and relationships \\
\hline 10 & $\begin{array}{l}\text { Modarresi et al., } \\
2018\end{array}$ & $\begin{array}{l}\text { Patients with OCD }(n=32) \\
\text { - control group }(n=16) \\
\text { - experimental group }(n=16)\end{array}$ & $\begin{array}{l}\text { 1- Control group: placebo (identical } \\
\text { pills) } \\
\text { 2- Experimental group: memantine } \\
10 \text { mg/day } \\
\text { - Patients continue their SRI therapy } \\
\text { during the study } \\
\text { - } 12 \text { wks follow up }\end{array}$ & $\begin{array}{l}\text { > Y-BOCS: Mean difference } 95 \% \mathrm{Cl} ; \\
-13.53[-15.59,-11.47] p \text { value }<0.001 \\
>\text { Adverse effects: Headache } \\
\text { 13.3\%Constipation6.6\% Nausea } 6.6 \% \\
\text { Dizziness 13.3\% Decreased appetite 6.6\% }\end{array}$ \\
\hline 11 & $\begin{array}{l}\text { Mowla et al., } \\
2019\end{array}$ & $\begin{array}{l}\text { Patients with OCD }(n=56) \\
\text { - control group }(n=28) \\
\text { - experimental group }(n=28) \\
\text { - the patients in this study had failed to } \\
\text { respond to at least } 12 \text { weeks of } \\
\text { treatment with an adequate and stable } \\
\text { dose of sertraline, as reflected by a } \\
\text { baseline Yale-Brown Obsessive } \\
\text { Compulsive Scale (YBOCS) of } 18 \text { or } \\
\text { greater before enrollment in our trial }\end{array}$ & $\begin{array}{l}\text { 1- Control group:sertraline + placebo } \\
\text { (identical pills } \\
\text { 2- Experimental group: Sertraline + } \\
\text { pregabalin }(75 \mathrm{mg} / \text { day initialy, } \\
\text { increase } 75 \mathrm{mg} \text { weekly } \\
\text { - The sertraline dosage had been tittered } \\
\text { up until patient's intolerance. } \\
\text { - No pregabalin dose escalation was } \\
\text { administered in the case of patient's } \\
\text { intolerance or clinical response. }\end{array}$ & $\begin{array}{l}>\text { Y-BOCS: Mean difference } 95 \% \mathrm{Cl} ; \\
-8.82[-11.17,-6.47] p \text { value }<0.001 \\
>\text { Adverse effects: Dizziness } 4 \% \\
\text { drowsiness } 18 \% \text {, headache } 4 \%\end{array}$ \\
\hline 12 & $\begin{array}{l}\text { Naderi et al., } \\
2019\end{array}$ & $\begin{array}{l}\text { Patients with OCD }(n=106) \\
\text { - control group }(n=53) \\
\text { - experimental group }(n=53) \\
\text { - The patients were not allowed to have } \\
\text { received any psychotropic medications } \\
\text { during the last } 6 \text { weeks or to have } \\
\text { participated in psychotropic sessions } \\
\text { - met the DSM-5 diagnostic criteria for } \\
\text { moderate to severe OCD and had a } \\
\text { Yale-Brown Obsessive Compulsive } \\
\text { Scale (Y-BOCS) score of }>21\end{array}$ & $\begin{array}{l}\text { 1- Control group: fluvoxamine ( } 100 \\
\text { mg twice a day) + placebo } \\
2 \text { - Experimental group: fluvoxamine } \\
\text { (100 mg twice a day) + amantadine } \\
\text { ( } 100 \mathrm{mg} \text { daily) } \\
\text { - All patients received } 100 \mathrm{mg} / \text { day } \\
\text { fluvoxamine for } 28 \text { days, which was } \\
\text { followed by } 200 \mathrm{mg} / \text { day for the rest of } \\
\text { the trial, regardless of their treatment } \\
\text { groups }\end{array}$ & $\begin{array}{l}>\text { Y-BOCS: Mean difference } 95 \% \mathrm{Cl}^{\prime}- \\
2.31[-4.58,-0.04] p \text { value:0.047 Ad- } \\
\text { verse effects: Abdominal pain (5.8\%) De- } \\
\text { creased appetite (3.9\%) Increased } \\
\text { appetite (3.9\%) Insomnia (1.9\%) Head- } \\
\text { ache (3.9\%) Nervousness (1.9\%) Tremor } \\
\text { (1.9\%) Constipation (3.9\%) }\end{array}$ \\
\hline 13 & $\begin{array}{l}\text { Paydari et al., } \\
2016\end{array}$ & $\begin{array}{l}\text { Patients with OCD }(n=46) \\
\text { - control group }(n=23) \\
\text { - experimental group }(n=23) \\
\text { - (DSM-IV TR) criteria of moderate-to- } \\
\text { severe OCD and scored } \geq 21 \text { in Y-BOCS }\end{array}$ & $\begin{array}{l}\text { 1- Control group: fluvoxamine ( } 200 \\
\text { mg daily) + placebo (identical pills) } \\
\text { 2- Experimental group: fluvoxamine } \\
\text { ( } 200 \mathbf{m g} \text { daily) + NAC ( } 2000 \text { mg daily) } \\
\text { - The NAC initial dosage was } 1000 \mathrm{mg} / \\
\text { day ( } 500 \mathrm{mg} \text { two times a day) for the } \\
\text { first week, followed by } 2000 \mathrm{mg} / \mathrm{day} \\
\text { (1000 mg bid) for the subsequent } 9 \\
\text { weeks } \\
\text { - } 10 \text { wks follow up }\end{array}$ & $\begin{array}{l}>\text { Y-BOCS: Mean difference } 95 \% \mathrm{Cl} ;- \\
2.04 \text { [- 4.97, - } 0.88] p \text { value:0.16 } \\
>\text { Adverse effects: Drowsiness, 18\% } \\
\text { Constipation 23\% Dizziness 27\% } \\
\text { Vomiting27\% Nausea27\% Headache18\% } \\
\text { Dry mouth14\% Increased blood } \\
\text { Pressure14\% Diarrhoea18\% }\end{array}$ \\
\hline 14 & $\begin{array}{l}\text { Pittenger et al., } \\
2015\end{array}$ & $\begin{array}{l}\text { Patients with OCD }(n=38) \\
\text { 1- control group }(n=18) \\
\text { 2- experimental group }(n=20) \\
\text { - treatment with an SSRI or } \\
\text { clomipramine at a stable effective dose } \\
\text { for } 8 \text { weeks (by patient report) is an } \\
\text { item in inclusion criteria }\end{array}$ & $\begin{array}{l}\text { 1- Control group: Placebo } \\
\text { 2- Experimental group: riluzole } \mathbf{5 0} \mathbf{~ m g} \\
\text { bid } \\
\text { - all subjects began with a 2-week } \\
\text { single-blind placebo lead-in phase, } \\
\text { followed by } 12 \text { weeks of double-blind } \\
\text { riluzole or placebo. In posttrial debrief- } \\
\text { ing, no subjects expressed awareness } \\
\text { of this initial placebo lead-in phase. } \\
\text { Any subjects experiencing a greater } \\
\text { than } 25 \% \text { improvement in the Y-BOCS } \\
\text { over this } 2 \text {-week placebo lead-in phase } \\
\text { were excluded from randomization. } \\
\text { - } 12 \text { wks follow up } \\
\text { - Low-dose stable neuroleptic augmenta- } \\
\text { tion and benzodiazepine use were } \\
\text { permitted } \\
\text { - Ongoing psychotherapy of } 12 \text { weeks } \\
\text { duration was permitted }\end{array}$ & $\begin{array}{l}>\text { Y-BOCS: Mean difference } 95 \% \mathrm{Cl}:- \\
4.5[-6.5074,-2.4926] p \text { value: } 0.002 \\
>\text { Adverse effects: Nausea: }<10 \% \text { in } \\
\text { experimental group }\end{array}$ \\
\hline 15 & Rodriguez 2013 & $\begin{array}{l}\text { Patients with OCD }(n=38) \\
\text { 1. control group }(n=18) \\
\text { 2. experimental group }(n=20) \\
\text { - Patients on average were off all } \\
\text { psychotropic medications for } 2.9 \text { years }\end{array}$ & $\begin{array}{l}\text { 1. Control group: Placebo (saline } \\
\text { infusion) } \\
\text { 2. Experimental group: Ketamine } \\
\text { infusion }(0.5 \mathrm{mg} / \mathrm{kg}) \\
\text { - Cross-over study } \\
\text { - One week duration }\end{array}$ & $\begin{array}{l}>\text { Y-BOCS: Mean difference } 95 \% \mathrm{Cl}- \\
5.46 \text { [- 13.15, 2.22] } p \text { value: } 0.1868 \\
>\text { Adverse effects: } \\
\text { o During infusion: Dissociation: } 93 \% \\
\text { unusual content of thought: } 87 \% \\
\text { elevated mood: } 7 \%\end{array}$ \\
\hline
\end{tabular}


Table 1 Controlled clinical trials reporting Glutamatergic drugs in OCD (Continued)

\begin{tabular}{|c|c|c|c|c|}
\hline & $\begin{array}{l}\text { Study (first } \\
\text { author, year of } \\
\text { study) }\end{array}$ & Study patients and main groups & Interventions & Outcomes, results and relationships \\
\hline & & & $\begin{array}{l}\text { - Include only the first period of study, } \\
\text { because of significant carryover effect }\end{array}$ & $\begin{array}{l}{ }^{\circ} \text { Post-infusion:dizziness } 20 \% \text { nausea: } \\
13 \% \text { headache } 13 \% \\
{ }^{\circ} \text { All side effects were resolved after } 110 \\
\text { min of infusion }\end{array}$ \\
\hline 16 & $\begin{array}{l}\text { Rutrick et al., } \\
2017\end{array}$ & $\begin{array}{l}\text { Patients with OCD }(n=50) \\
\text { 1. control group }(n=24) \\
\text { 2. experimental group }(n=26) \\
\text { - All patients had used SRI for 12wks } \\
\text { before baseline and had insufficient } \\
\text { response (Y-BOCS score }>16)\end{array}$ & $\begin{array}{l}\text { 1. Control group: Placebo } \\
\text { 2. Experimental group: Magovlurant } \\
\mathbf{2 0 0} \text { mg BiD } \\
\text { - } 19 \text { wks follow up. First } 4 \text { wks for dose } \\
\text { titration and last } 3 \text { wks for taper of } \\
\text { mavoglurant } \\
\text { - During the study patients remained on } \\
\text { their SSRI treatment } \\
\text { - Patients who were receiving cognitive } \\
\text { behavioral therapy (CBT) as a part of } \\
\text { their standard care continued to } \\
\text { receive this therapy for the duration of } \\
\text { the study. }\end{array}$ & $\begin{array}{l}>\text { Y-BOCS: Mean difference } 95 \% \mathrm{Cl} 1.80 \\
\text { [-4.30, 7.90] } p \text { value: } 0.5658 \\
>\text { Adverse effects [placebo(\%) vs } \\
\text { experimental(\%)]: Headache } 8 \text { (33.3) } 10 \\
\text { (38.5) Insomnia } 2 \text { (8.3) } 6 \text { (23.1) Dizziness } \\
2 \text { (8.3) } 5 \text { (19.2) Nasopharyngitis } 4 \text { (16.7) } 2 \\
\text { (7.7) Abdominal pain upper } 1 \text { (4.2) } 2 \text { (7.7) } \\
\text { Abnormal dreams } 1 \text { (4.2) } 2 \text { (7.7) AST } \\
\text { increased } 1 \text { (4.2) } 2 \text { (7.7) Depression } 2 \\
\text { (8.3) } 1 \text { (3.8) Fatigue } 1 \text { (4.2) } 2 \text { (7.7) Vertigo } \\
1 \text { (4.2) } 2 \text { (7.7) }\end{array}$ \\
\hline 17 & Sarris et al., 2015 & $\begin{array}{l}\text { Patients with OCD }(n=50) \\
\text { 1. control group }(n=24) \\
\text { 2. experimental group }(n=26) \\
\text { - patients were on either no treatment } \\
\text { or a stable treatment regimen for a } \\
\text { minimum of four weeks of current } \\
\text { treatment and a minimum of } 12 \text { weeks } \\
\text { if this is their first OCD treatment }\end{array}$ & $\begin{array}{l}\text { 1. Control group: Same shaped } \\
\text { cellulose capsule } \\
\text { 2. Experimental group: NAC } 3000 \text { mg/ } \\
\text { day } \\
\text { - } 16 \text { wks follow up } \\
\text { - NAC was titrated, } 1000 \mathrm{mg} / \text { day in week } \\
\text { 1, } 2000 \mathrm{mg} / \text { day in week } 2\end{array}$ & $\begin{array}{l}>\text { Y-BOCS: Mean difference } 95 \% \mathrm{Cl} ;- \\
2.04-0.59[-6.31,5.13] p \text { value: } 0.8425 \\
>\text { Adverse effects: heartburn } 20 \%\end{array}$ \\
\hline
\end{tabular}

placebo group. A treatment response was significantly more likely in the glutamate-mediating-augmentation group than in the placebo-augmentation group $(\mathrm{z}=-$ 3.83, $P<0.001)$. Details of the studies are described in Table 1. Diagram 1 illustrates the forest plot of analyses of the included studies. The results of the assessment of studies for six main biases are shown in Fig. 2. The
Funnel plot graph for the studies included is shown in Fig. 3. As can be seen, the overall quality of studies was fair (Table 2).

\section{Memantine}

Memantine is one of the approved medications for moderate to severe Alzheimer's disease. It is a non-

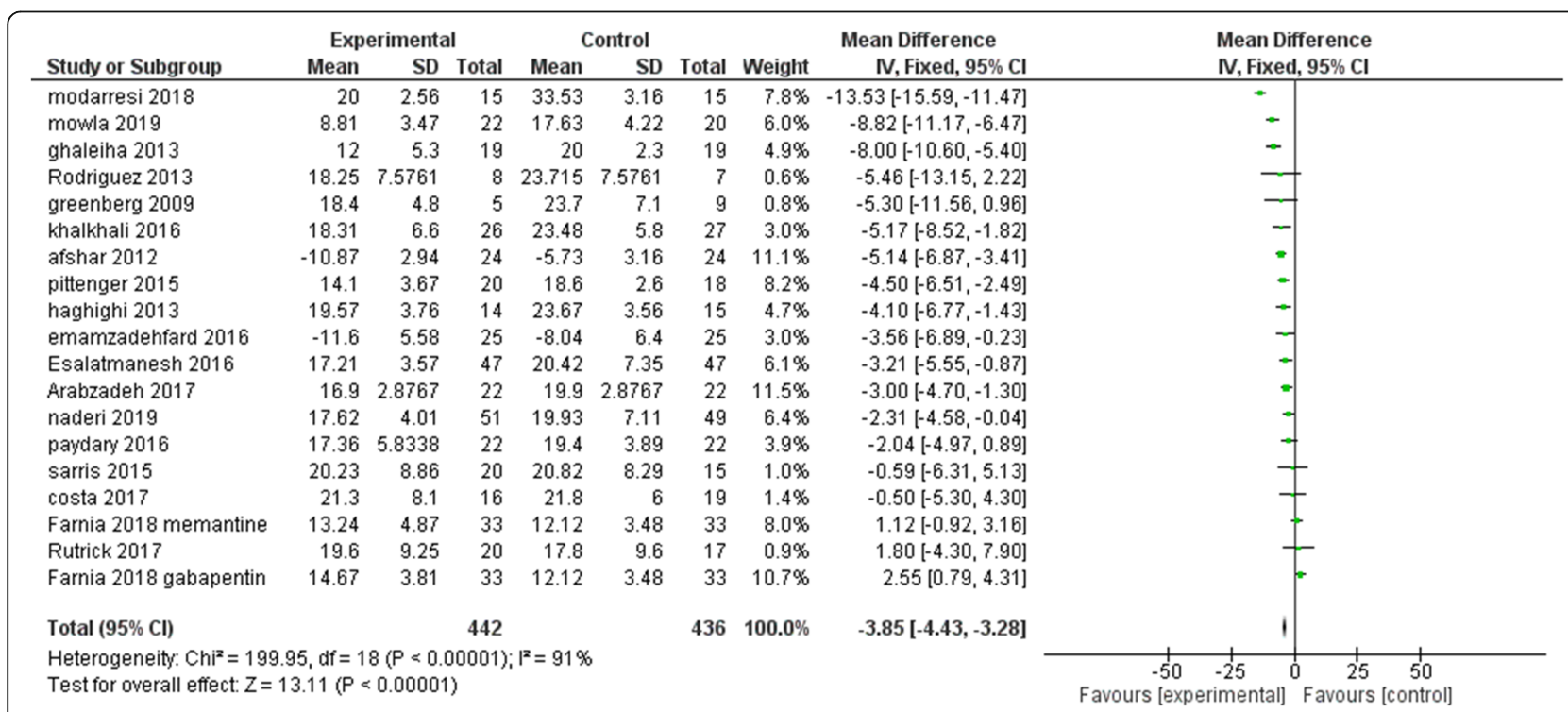

Fig. 2 Comparison of Y-BOCS score between patients with moderate to severe OCD groups and control groups in each of the studies and in overall meta-analysis 


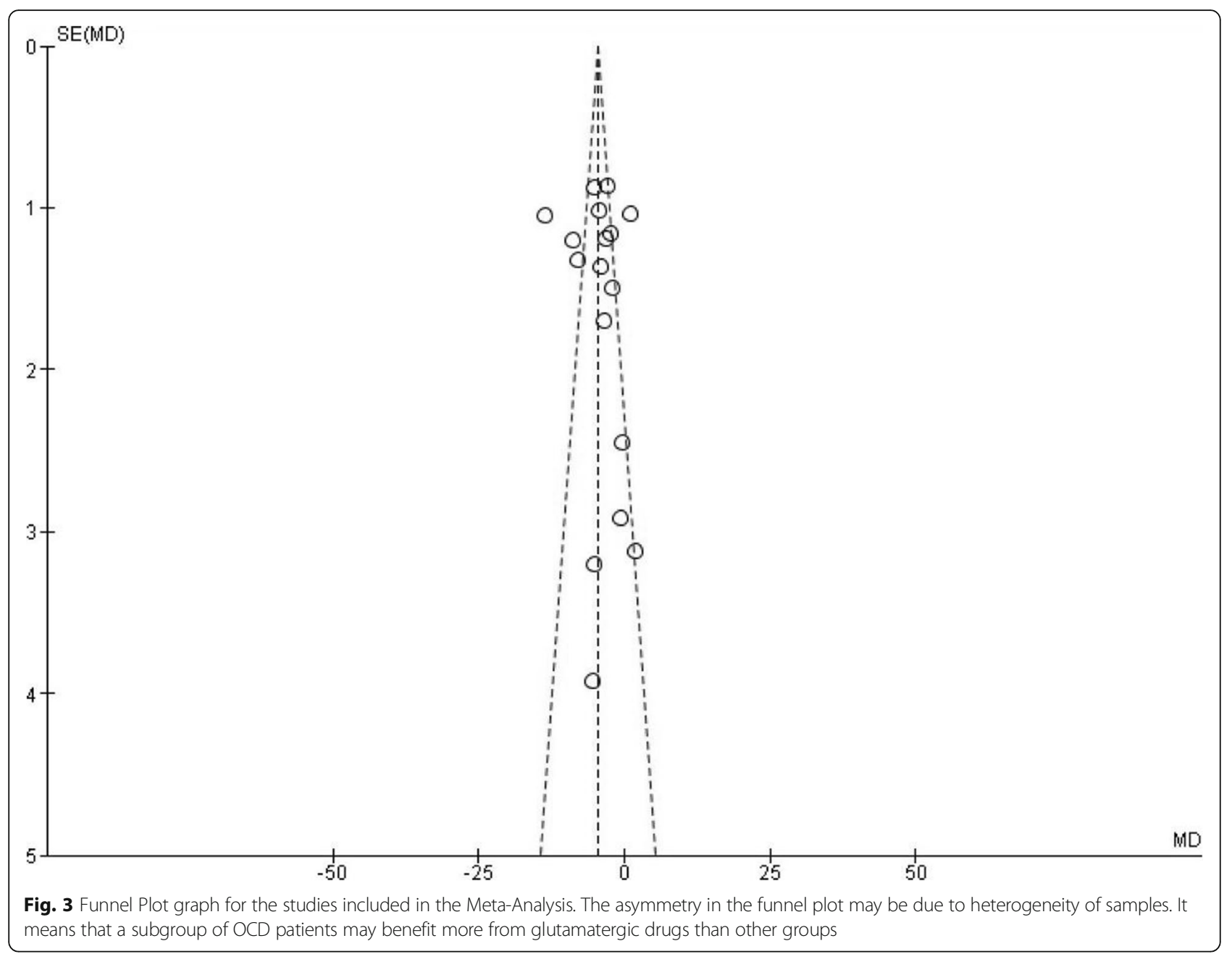

competitive antagonist of NMDA receptor, one of the main receptors of glutamatergic system [22]. Memantine blocks the effects of sustained, pathologically elevated levels of glutamate that may otherwise lead to neuronal dysfunction [23].

Four of seventeen studies in this review included memantine as an adjuvant therapy. In three of these studies reporting final Y-BOCS scores, the mean difference of Y-BOCS score between two groups with $95 \%$ confidence interval was $-5.68[-6.96,-4.41]$ ( $P$-value< 0.0001).

One of the studies only reported the remission rate of the responders (>35\% decrease in Y-BOCS score). In which, $89 \%$ of the patients in the memantine group compared with $32 \%$ of the patients in the placebo group achieved remission $(x 2(1)=13.328, P<0.001)$ [24].

\section{Minocycline}

Minocycline is a known glutamatergic agent with therapeutic effects on neurodegenerative diseases which might be achieved through the blockade of glutamate- mediated excitotoxicity. Moreover, this antibiotic is known for its antioxidant and anti-inflammatory characteristics, which could further explain its neuroprotective effects. The beneficial role of minocycline in the treatment of schizophrenia, depressive and autistic symptoms is reported in previous research $[25,26]$.

In one of the studies, the efficacy of minocycline was assessed as an augmentative agent to fluvoxamine in the treatment of patients with OCD [27]. Significantly lower Y-BOCS scores were achieved in the minocycline group compared to the placebo group at the end of the study (t-score: $-2.84, P$ value: 0.0084 ).

\section{L-carnosine}

L-carnosine is a nutritional complementary agent with both antioxidant and glutamatergic properties. Carnosine reduces the glutamate levels in the central nervous system via upregulation of the glutamate transporter 1 [28-30]. One of the studies assessed the effect of Lcarnosine as adjunct therapy to fluvoxamine in OCD 
Table 2 Table of risk of bias for included studies considering Cochrane 'Risk of bias' tool. The overall quality of studies was fair

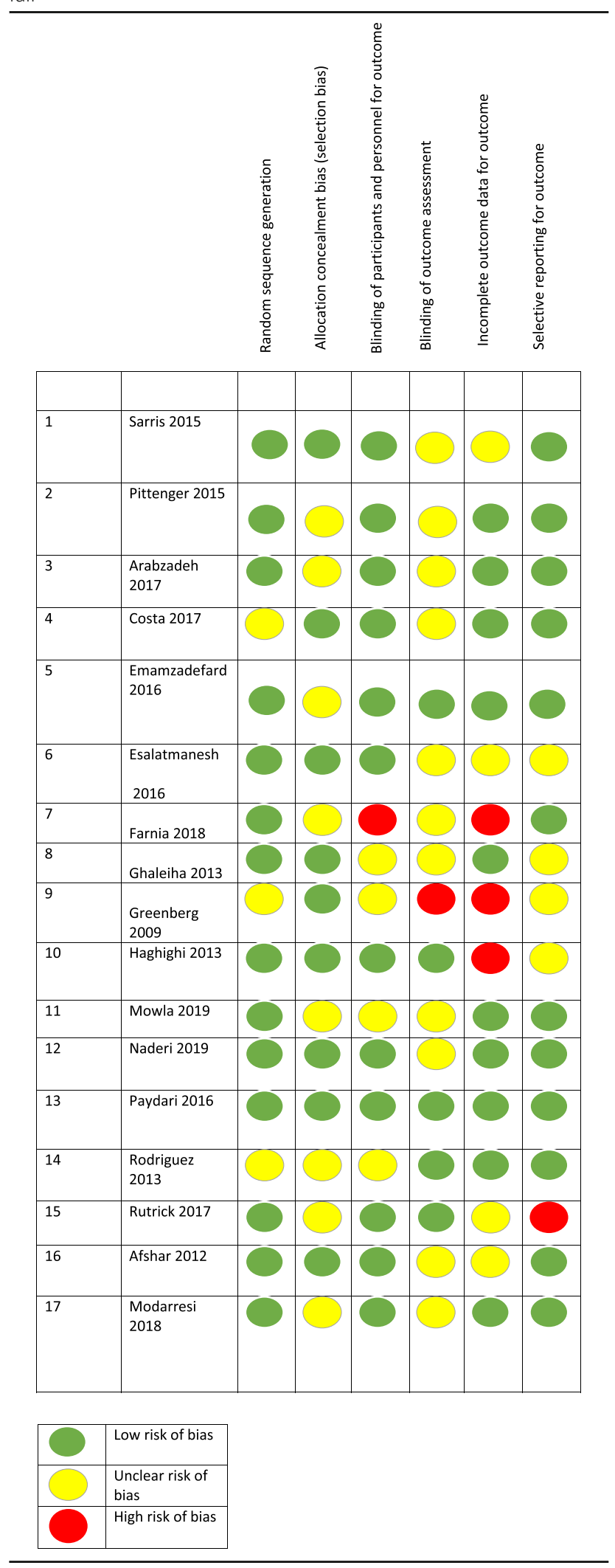

and found significant decrease in final Y-BOCS score (t42:-2.62, $P$-value: $<0.001)$ [31].

\section{Riluzole}

Riluzole, an anti-glutamatergic agent, is mainly known as a treatment of Amyotrophic Lateral Sclerosis (ALS) [32]. A 10-weeks randomized placebo-controlled trial examined the efficacy of riluzole in the management of OCD. This study showed significant improvement in the patients treated with Riluzole [33]. Two studies were found which used Riluzole for the trial [34]. The reduction of Y-BOCS score at the end of studies were significantly lower than control group. $[\mathrm{Z}=4.85(P<0.00001)]$.

\section{$\mathrm{N}$-acetylcysteine (NAC)}

$\mathrm{NAC}$ is known as a regulator of glutamatergic system and can prevent pre-oxidant effect of glutamate. It has been proposed as a potential therapy for OCD since it can regulate the exchange of glutamate and prevent its pre-oxidant effects [35]. Four studies in this review included this medication. In the analysis of these studies, there was a significant decrease in the Y-BOCS scores in the experimental group [Z = 5.4(P: 0.000139)] [36-39].

\section{Discussion}

Many glutamate-modulating drugs have been reported to have clinical efficacy in the treatment of OCD. As previously mentioned, riluzole which is an antiglutamate drug, can be effective in the treatment of refractory OCD. This therapeutic effect can be considered an evidence for the abnormal elevation of glutamate in the CNS of patients with OCD [40, 41].

Based on the findings of this review, memantine has strong evidence supporting its clinical efficacy in the treatment of OCD which is in agreement with previous reviews [42]. Additionally, there is promising evidence on the therapeutic effects of riluzole and NAC in other studies $[43,44]$. There is also confirmative data on the potential utility of minocycline by Marinova et al. [19]. Other medications with different mechanisms have also been proposed to be effective in the treatment of OCD. For instance, topiramate (through gamma-Aminobutyric acid (GABA) and AMPA/kainite-type glutamate receptors) [45] and lamotrigine (through GABA and reduction of the presynaptic release of glutamate [46], have shown some efficacy in patients with OCD. Moreover, Dcycloserine, a partial agonist of NMDA receptor, has demonstrated some supporting evidence $[10,15,34,42$, $44,45]$, but we did not find any eligible study on these drugs. However, it is unfortunate that this study did not include data reported in peer-reviewed publications other than journal articles. Therefore, it is important to bear in mind the possibility of publication bias. 


\section{Conclusions}

In summary, there is supporting evidence for glutamatemodulating drugs in treating moderate to severe OCD as an alternative or adjunctive therapy. In the present review we found evidence for several drugs such as memantine, NAC, minocycline, L-carnosine and riluzole. Further research is needed to determine neuroanatomical, neurochemical and basic genetics for the new line of treatments in OCD. The efficacy, effectiveness and risks associated with these glutamate- modulating drugs for the treatment of moderate to severe OCD should be further investigated. In future investigations, it would also be interesting to identify and analyze possible moderator variables.

\section{Abbreviations}

OCD: Obsessive-compulsive disorder; SSRIs: Selective Serotonin Reuptake Inhibitors; CSTC: Cortico-striato-thalamo-cortical; CNS: Central Nervous System; ASD: Autism Spectrum Disorder; MDD: Major Depressive Disorder; GABA: Gamma-Aminobutyric acid; NMDA: N-methyl-d-aspartate; AMPA: aamino-3-hydroxy-5-methyl-4-isoxazolepropionic acid; OFC: Orbitofrontal cortex; ACC: Anterior Cingulate Cortex; CSF: Cerebrospinal fluid; MRS: Magnetic Resonance Spectroscopy; EAAT3: Excitatory amino acid transporter 3; SAPAPs: Synapse associated protein 90/postsynaptic density95-associated proteins; DLGAPs: Disks large-associated proteins; NAC: Nacetylcysteine; Y-BOCS: Yale-Brown obsessive-compulsive score; ALS: Amyotrophic Lateral Sclerosis

\section{Supplementary Information}

The online version contains supplementary material available at https://doi. org/10.1186/s40360-021-00534-6.

Additional file 1

\section{Acknowledgments}

We would like to appreciate Dr. Armin Hirbod-Mobarake for his helpful cooperation in data analysis.

\section{Authors' contributions}

Conceptualization and design: FH, LK, and MS; Data collection: FH, SK, SH and MS; Initial draft preparation: FH, SK, LK and MS; Editing \& review: All authors. The author(s) read and approved the final manuscript.

\section{Funding}

This research received no specific grant from any funding agency in the public, commercial, or not-for-profit sectors.

\section{Availability of data and materials}

The datasets used and analyzed during the current study are available from the corresponding author on reasonable request.

\section{Declarations}

\section{Ethics approval and consent to participate}

Because of the type of article (Review), there was no need for obtaining ethical approval.

\section{Consent for publication}

Not applicable.

\section{Competing interests}

The authors have no conflicts of interest to report.

\section{Author details}

${ }^{1}$ School of Medicine, Shahid Beheshti University of Medical Sciences, Tehran, Iran. ${ }^{2}$ Mental Health Research Center, Psychosocial Health Research Institute, Department of Psychiatry, School of Medicine, Iran University of Medical Sciences, Tehran, Iran. ${ }^{3}$ Roozbeh Psychiatric Hospital, Tehran University of Medical Sciences, Tehran, Iran. ${ }^{4}$ Brain and Cognition Clinic, Institute for Cognitive Sciences Studies, Tehran, Iran.

Received: 5 April 2021 Accepted: 20 October 2021

Published online: 04 November 2021

\section{References}

1. American Psychiatric Association. Diagnostic and statistical manual of mental disorders (DSM-5 ${ }^{\oplus}$ ): American Psychiatric Pub; 2013.

2. Fawcett EJ, Power $\mathrm{H}$, Fawcett JM. Women are at greater risk of OCD than men: a meta-analytic review of OCD prevalence worldwide. J Clin Psychiatry. 2020;81(4):0.

3. Sinopoli VM, Burton $\mathrm{CL}$, Kronenberg S, Arnold PD. A review of the role of serotonin system genes in obsessive-compulsive disorder. Neurosci Biobehav Rev. 2017:80:372-81. https://doi.org/10.1016/..neubiorev.2017.05.029.

4. Nabizadeh $M$. The role of serotonin and dopamine neurotransmitters in obsessive-compulsive disorder. Neurosci J Shefaye Khatam. 2019;7(2):99_ 106. https://doi.org/10.29252/shefa.7.2.99.

5. Shalbafan M, Malekpour F, Tadayon Najafabadi B, Ghamari K, Dastgheib S-A, Mowla A, et al. Fluvoxamine combination therapy with tropisetron for obsessive-compulsive disorder patients: a placebo-controlled, randomized clinical trial. J Psychopharmacol. 2019;33(11):1407-14. https://doi.org/10.11 77/0269881119878177.

6. Reddy YJ, Sundar AS, Narayanaswamy JC, Math SB. Clinical practice guidelines for obsessive-compulsive disorder. Indian J Psychiatry. 2017; 59(Suppl 1):S74. https://doi.org/10.4103/0019-5545.196976.

7. Karthik S, Sharma LP, Narayanaswamy JC. Investigating the role of glutamate in obsessive-compulsive disorder: current perspectives. Neuropsychiatr Dis Treat. 2020;16:1003-13. https://doi.org/10.2147/NDT.S211703.

8. Naaijen J, Zwiers MP, Amiri H, Williams SC, Durston S, Oranje B, et al. Frontostriatal glutamate in autism spectrum disorder and obsessive compulsive disorder. Neuropsychopharmacology. 2017;42(12):2456-65. https://doi.org/1 0.1038/npp.2016.260

9. Magi S, Piccirillo S, Amoroso S, Lariccia V. Excitatory amino acid transporters (EAATs): glutamate transport and beyond. Int J Mol Sci. 2019;20(22):5674. https://doi.org/10.3390/ijms20225674.

10. Vlček P, Polák J, Brunovský M, Horáček J. Role of glutamatergic system in obsessive-compulsive disorder with possible therapeutic implications. Pharmacopsychiatry. 2018;51(06):229-42. https://doi.org/10.1055/s-0043-11 8665 .

11. Hollestein V, Buitelaar JK, Brandeis D, Banaschewski T, Kaiser A, Hohmann S, et al. Developmental changes in fronto-striatal glutamate and their association with functioning during inhibitory control in autism spectrum disorder and obsessive compulsive disorder. Neurolmage Clinical. 2021;30: 102622

12. Rosenberg DR, MacMillan SN, Moore GJ. Brain anatomy and chemistry may predict treatment response in paediatric obsessive-compulsive disorder. Int J Neuropsychopharmacol. 2001;4(2):179-90. https://doi.org/10.1017/S146114 5701002401.

13. Chakrabarty K, Bhattacharyya S, Christopher R, Khanna S. Glutamatergic dysfunction in OCD. Neuropsychopharmacology. 2005;30(9):1735-40. https://doi.org/10.1038/sj.npp.1300733.

14. Bhattacharyya S, Khanna S, Chakrabarty K, Mahadevan A, Christopher R, Shankar S. Anti-brain autoantibodies and altered excitatory neurotransmitters in obsessive-compulsive disorder. Neuropsychopharmacology. 2009;34(12):2489-96. https://doi.org/10.1038/ npp.2009.77.

15. Naaijen J, Lythgoe DJ, Amiri H, Buitelaar JK, Glennon JC. Fronto-striatal glutamatergic compounds in compulsive and impulsive syndromes: a review of magnetic resonance spectroscopy studies. Neurosci Biobehav Rev. 2015:52:74-88. https://doi.org/10.1016/..neubiorev.2015.02.009.

16. Pittenger $C$. Glutamatergic agents for OCD and related disorders. Curr Treat Options Psychiatry. 2015;2(3):271-83. https://doi.org/10.1007/s40501-0150051-8.

17. Pittenger $\mathrm{C}$, Bloch $\mathrm{MH}$, Williams K. Glutamate abnormalities in obsessive compulsive disorder: neurobiology, pathophysiology, and treatment. 
Pharmacol Ther. 2011;132(3):314-32. https://doi.org/10.1016/j.pharmthera.2 011.09.006.

18. Kim HW, Kang Jl, Hwang EH, Kim SJ. Association between glutamate transporter gene polymorphisms and obsessive-compulsive disorder/trait empathy in a Korean population. PLoS One. 2018;13(1):e0190593. https:// doi.org/10.1371/journal.pone.0190593.

19. Marinova Z, Chuang D-M, Fineberg N. Glutamate-modulating drugs as a potential therapeutic strategy in obsessive-compulsive disorder. Curr Neuropharmacol. 2017;15(7):977-95. https://doi.org/10.2174/1570159X1 5666170320104237.

20. Liberati A, Altman DG, Tetzlaff J, Mulrow C, Gøtzsche PC, loannidis JP, et al. The PRISMA statement for reporting systematic reviews and meta-analyses of studies that evaluate health care interventions: explanation and elaboration. J Clin Epidemiol. 2009;62(10):e1-e34. https://doi.org/10.1016/j. jclinepi.2009.06.006.

21. Higgins JP, Altman DG, Gøtzsche PC, Jüni P, Moher D, Oxman AD, et al. The Cochrane Collaboration's tool for assessing risk of bias in randomised trials. BMJ. 2011;343(oct18 2):d5928. https://doi.org/10.1136/bmj.d5928.

22. Lu S, Nasrallah HA. The use of memantine in neuropsychiatric disorders: an overview. Ann Clin Psychiatry. 2018;30(3):234-48.

23. Sani G, Serra G, Kotzalidis GD, Romano S, Tamorri SM, Manfredi G, et al. The role of memantine in the treatment of psychiatric disorders other than the dementias. CNS Drugs. 2012;26(8):663-90. https://doi.org/10.2165/11634390000000000-00000

24. Ghaleiha A, Entezari N, Modabbernia A, Najand B, Askari N, Tabrizi M, et al. Memantine add-on in moderate to severe obsessive-compulsive disorder: randomized double-blind placebo-controlled study. J Psychiatr Res. 2013; 47(2):175-80. PubMed PMID: 23063327. Epub 2012/10/16. eng. https://doi. org/10.1016/j.jpsychires.2012.09.015

25. Khodaie-Ardakani M-R, Mirshafiee O, Farokhnia M, Tajdini M, Modabbernia A, Rezaei F, et al. Minocycline add-on to risperidone for treatment of negative symptoms in patients with stable schizophrenia: randomized double-blind placebo-controlled study. Psychiatry Res. 2014;215(3):540-6. https://doi.org/1 0.1016/j.psychres.2013.12.051

26. Emadi-Kouchak H, Mohammadinejad P, Asadollahi-Amin A, Rasoulinejad M, Zeinoddini A, Yalda A, et al. Therapeutic effects of minocycline on mild-tomoderate depression in HIV patients: a double-blind, placebo-controlled, randomized trial. Int Clin Psychopharmacol. 2016;31(1):20-6. https://doi. org/10.1097/YIC.0000000000000098.

27. Esalatmanesh S, Abrishami Z, Zeinoddini A, Rahiminejad F, Sadeghi M, Najarzadegan MR, et al. Minocycline combination therapy with fluvoxamine in moderate-to-severe obsessive-compulsive disorder: a placebo-controlled, double-blind, randomized trial. Psychiatry Clin Neurosci. 2016;70(11):517-26. https://doi.org/10.1111/pcn.12430.

28. Shen $Y$, He P, Fan Y-y, Zhang J-x, Yan H-j, Hu W-w, et al. Carnosine protects against permanent cerebral ischemia in histidine decarboxylase knockout mice by reducing glutamate excitotoxicity. Free Radic Biol Med. 2010;48(5): 727-35. https://doi.org/10.1016/j.freeradbiomed.2009.12.021.

29. Ghajar A, Khoaie-Ardakani M-R, Shahmoradi Z, Alavi A-R, Afarideh M, Shalbafan M-R, et al. L-carnosine as an add-on to risperidone for treatment of negative symptoms in patients with stable schizophrenia: a double-blind, randomized placebo-controlled trial. Psychiatry Res. 2018;262:94-101. https://doi.org/10.1016/j.psychres.2018.02.012.

30. Araminia B, Shalbafan M, Mortezaei A, Shirazi E, Ghaffari S, Sahebolzamani E, et al. L-carnosine combination therapy for major depressive disorder: a randomized, double-blind, placebo-controlled trial. J Affect Disord. 2020;267: 131-6. https://doi.org/10.1016/j.jad.2020.02.020.

31. Arabzadeh S, Shahhossenie M, Mesgarpour B, Rezaei F, Shalbafan MR, Ghiasi Z, et al. L-carnosine as an adjuvant to fluvoxamine in treatment of obsessive compulsive disorder: a randomized double-blind study. Hum Psychopharmacol Clin Exp. 2017;32(4):e2584. https:/doi.org/10.1002/hup.2584.

32. Miller RG, Mitchell JD, Moore DH. Riluzole for amyotrophic lateral sclerosis (ALS)/motor neuron disease (MND). Cochrane Database Syst Rev. 2000;2: CD001447 PubMed PMID: 10796796. Epub 2000/05/05. eng.

33. Emamzadehfard S, Kamaloo A, Paydary K, Ahmadipour A, Zeinoddini A, Ghaleiha A, et al. Riluzole in augmentation of fluvoxamine for moderate to severe obsessive-compulsive disorder: R andomized, double-blind, placebocontrolled study. Psychiatry Clin Neurosci. 2016;70(8):332-41. https://doi. org/10.1111/pcn.12394

34. Pittenger C, Bloch MH, Wasylink S, Billingslea E, Simpson R, Jakubovski E, et al. Riluzole augmentation in treatment-refractory obsessive-compulsive disorder: a pilot randomized placebo-controlled trial. J Clin Psychiatry. 2015; 76(8):1075-84. PubMed PMID: 26214725. Pubmed Central PMCID: PMC4 560666. Epub 2015/07/28. eng. https://doi.org/10.4088/JCP.14m09123.

35. Dean O, Giorlando F, Berk M. N-acetylcysteine in psychiatry: current therapeutic evidence and potential mechanisms of action. J Psychiatry Neurosci. 2011;36(2):78-86. https://doi.org/10.1503/jpn.100057.

36. Afshar $\mathrm{H}$, Roohafza $\mathrm{H}$, Mohammad-Beigi $\mathrm{H}$, Haghighi M, Jahangard L, Shokouh P, et al. N-acetylcysteine add-on treatment in refractory obsessivecompulsive disorder: a randomized, double-blind, placebo-controlled trial. J Clin Psychopharmacol. 2012;32(6):797-803. https://doi.org/10.1097/JCP. Ob013e318272677d.

37. Costa DL, Diniz JB, Requena G, Joaquim MA, Pittenger C, Bloch MH, et al. Randomized, double-blind, placebo-controlled trial of $\mathrm{N}$-acetylcysteine augmentation for treatment-resistant obsessive-compulsive disorder. J Clin Psychiatry. 2017;78(7):0.

38. Paydary K, Akamaloo A, Ahmadipour A, Pishgar F, Emamzadehfard S, Akhondzadeh S. N-acetylcysteine augmentation therapy for moderate-tosevere obsessive-compulsive disorder: randomized, double-blind, placebocontrolled trial. J Clin Pharm Ther. 2016:41(2):214-9. https://doi.org/10.1111/ jcpt.12370.

39. Sarris J, Oliver G, Camfield DA, Dean OM, Dowling N, Smith DJ, et al. Nacetyl cysteine (NAC) in the treatment of obsessive-compulsive disorder: a 16-week, double-blind, randomised, placebo-controlled study. CNS Drugs. 2015;29(9):801-9. https://doi.org/10.1007/s40263-015-0272-9.

40. Pittenger C, Krystal JH, Coric V. Glutamate-modulating drugs as novel pharmacotherapeutic agents in the treatment of obsessive-compulsive disorder. NeuroRx. 2006;3(1):69-81. https://doi.org/10.1016/j.nurx.2005.12.006.

41. Grant P, Song JY, Swedo SE. Review of the use of the glutamate antagonist riluzole in psychiatric disorders and a description of recent use in childhood obsessive-compulsive disorder. J Child Adolesc Psychopharmacol. 2010; 20(4):309-15. https://doi.org/10.1089/cap.2010.0009.

42. Sheshachala K, Narayanaswamy JC. Glutamatergic augmentation strategies in obsessive-compulsive disorder. Indian J Psychiatry. 2019;61(Suppl 1):S5865. https://doi.org/10.4103/psychiatry.IndianJPsychiatry_520_18.

43. Wu K, Hanna GL, Rosenberg DR, Arnold PD. The role of glutamate signaling in the pathogenesis and treatment of obsessive-compulsive disorder. Pharmacol Biochem Behav. 2012;100(4):726-35. https://doi.org/10.1016/j. pbb.2011.10.007.

44. Fineberg NA, Brown A, Reghunandanan S, Pampaloni I. Evidence-based pharmacotherapy of obsessive-compulsive disorder. Int J Neuropsychopharmacol. 2012;15(8):1173-91. https://doi.org/10.1017/S14 61145711001829.

45. Ting JT, Feng G. Glutamatergic synaptic dysfunction and obsessivecompulsive disorder. Curr Chemical Genomics. 2008;2:62-75. https://doi. org/10.2174/1875397300802010062

46. Grados MA, Atkins EB, Kovacikova Gl, McVicar E. A selective review of glutamate pharmacological therapy in obsessive-compulsive and related disorders. Psychol Res Behav Manag. 2015;8:115. https://doi.org/10.2147/ PRBM.S58601.

\section{Publisher's Note}

Springer Nature remains neutral with regard to jurisdictional claims in published maps and institutional affiliations.

Ready to submit your research? Choose BMC and benefit from:

- fast, convenient online submission

- thorough peer review by experienced researchers in your field

- rapid publication on acceptance

- support for research data, including large and complex data types

- gold Open Access which fosters wider collaboration and increased citations

- maximum visibility for your research: over $100 \mathrm{M}$ website views per year

At $\mathrm{BMC}$, research is always in progress.

Learn more biomedcentral.com/submissions 